\title{
QUALITY OF LIFE IN PATIENTS WITH CHRONIC PANCREATITIS AND RELATED ANEMIA
}

\author{
@M. V. Palykhata, L. S. Babinets, O. V. Pronyuk \\ I. Horbachevsky Ternopil State Medical University
}

SUMMARY. The study of QOL is one of the urgent problems in medicine in the world. The quality of life (QOL) is a reliable and valid instrument for measuring quality of life from the perspective of the patient. The scale is often used with confidence in patients with chronic diseases requiring long-term therapy. The cognitive impairment in young women, a greater risk of mortality and hospitalizations in adults and especially in elderly, dysfunction of thermoregulation and immune system, gastrointestinal disorders, Helicobacter pylori infection are more found in patients with CP and related anemia, which reduces QOL even more. Our study of QOL in patients with chronic pancreatitis (CP) and CP with related anemic syndrome by questionnaires SF-36 and GSRS, demonstrated significantly lower level of QOL in patients with related anemia. This objectively affirms an aggravating role of related anemia in the course of main disease.

KEY WORDS: chronic pancreatitis; anemia; quality of life; SF-36; GSRS.

The study of QOL is one of the urgent problems in medicine in the world. Its assessment is particularly important in chronic diseases requiring long-term therapy. The cognitive impairment in young women, a greater risk of mortality and hospitalizations in adults and especially in elderly, dysfunction of thermoregulation and immune system, gastrointestinal disorders, Helicobacter pylori infection are more found in patients with $\mathrm{CP}$ and related anemia, which reduces $\mathrm{QOL}$ even more.

The aim of the study - to compare QOL of patients with $\mathrm{CP}$ and related anemic syndrome.

Materials and methods. Retrospectively analyzed 50 case histories of hospitalized patients with CP who were treated in day care TCMH №2 in 2015-2017 years. Patients were divided into two groups: the first included 21 patients with $C P$, the second - 29 patients with $\mathrm{CP}$, combined with anemic syndrome.

Results. QOL of patients were determined by using the general questionnaire Medical Outcomes Study 36-Itm (Mos SF-36), in which 36 points are grouped into 8 scales. Each scale is directly transformed into a 0-100 scale, a score of 100 is equivalent to no disability. The results of the questionnaire: the physical functioning in patients with $\mathrm{CP}$ is (81.6 \pm 3.05$)$ points, and for CP with anemia - (61.6 \pm 2.8$)$, physical role functioning - $(53.5 \pm 9.9)$

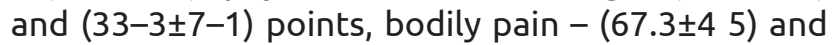
$(55.3 \pm 3.3)$ points, general health perceptions $(51.6 \pm 3.7)$ and $(41.6 \pm 3.1)$ points, vitality - $(54 \pm 4.3)$ and $(40 \pm 4.1)$ points, social role functioning $(81.4 \pm 4.4)$ and $(75.3 \pm 3.7)$ points, emotional role functioning - (65 \pm 9.8$)$ and (66.6 \pm 6.8$)$, mental health $-(62 \pm 4.3)$ and $(63 \pm 3.9)$ points respectively. To assess the severity of gastroenterological symptoms and QOL we used the Russian version of a special questionnaire Gastrointestinal Symptom Rating Scale (GSRS), witch consist of 15 questions, grouped into five scales: abdominal pain (AP), reflux syndrome (RS), constipation syndrome (CS), diarrheal syndrome (DS), indigestion syndrome (IS). Number scales ranging from 1 to 7 , higher values are responsible for more severe symptoms and lower QOL. Patients with CP: AP syndrome was $(2.5 \pm 0.25)$ points, and in patients with related anemia - $(2.8 \pm 0.3)$ points, RS $(4.00 \pm 0.23)$ and $(1.76 \pm 0.21)$ points, CS $-(1.50 \pm 0.27)$ and $(2.66 \pm 0.21)$ points, DS - $(1.90 \pm 0.20)$ and $(1.98 \pm 0.20)$, IS $-(3.50 \pm 0.24)$ and $(2.80 \pm 0.23)$ points respectively.

Conclusions. In patients with $\mathrm{CP}$ and related anemia is significantly lower level of QOL, describing the physical condition and higher level of DS, CS, AP specific pathology of the gastrointestinal tract questionnaire GSRS on such group patients with CP without anemia. This objectively affirms an aggravating role of related anemia in the course of CP.

Perspectives of the further investigations. In the future we plan to research role of related anemia in the course of CP deeper to offer correction programs and thus to make better QOL in such patients. 


\title{
Огляди літератури, оригінальні дослідження, погляд на проблему, короткі повідомлення
}

\section{ЯКІСТЬ ЖИТТЯ ПАЦІЄНТІВ ІЗ ХРОНІЧНИМ ПАНКРЕАТИТОМ І СУПУТНЬОЮ АНЕМІЄЮ}

\author{
๑М. В. Палихата, Л. С. Бабінець, О. В. Пронюк
}

ДВНЗ «Тернопільський державний медичний університет імені І. Я. Горбачевського мОз України»

РЕЗЮМЕ. Вивчення якості життя (ЯЖ) у всьому світі є однією з актуальних проблем у медицині. Опитувальники $\epsilon$ надійним і дієвим інструментом для вимірювання ЯЖ з точки зору пацієнта. Шкала часто використовується 3 упевненістю у пацієнтів з хронічними захворюваннями, що потребують довготривалої терапії. У пацієнтів із хронічним панкреатитом (ХП) і супутньою анемією частіше зустрічаються супутні когнітивні порушення у молодих жінок, більший ризик летальності та госпіталізацій у дорослих і особливо у пацієнтів літнього віку, порушення терморегуляції, дисфункція імунної системи, шлунково-кишкові розлади, інфекція Helicobacter pylori, які ще більше знижують ЯЖ. Наше дослідження ЯЖ у пацієнтів із ХП та ХП із супутнім анемічним синдромом за допомогою опитувальників SF-36 і GSRS, продемонстрували значно нижчий рівень ЯЖ у пацієнтів із анемією. Це свідчить про об'єктивний обтяжувальний вплив супутньої анемії на перебіг основного захворювання.

КлючОВI СлОВА: хронічний панкреатит; анемія; якість життя; SF-36; GSRS.

\section{КАЧЕСТВО ЖИЗНИ ПАЦИЕНТОВ С ХРОНИЧЕСКИМ ПАНКРЕАТИТОМ И СОПУТСТВУЮЩЕЙ АНЕМИЕЙ}

ОМ. В. Палихата, Л. С. Бабинец, А. В. Пронюк

ДвНЗ «Тернопольский государственный медицинский университет имени И. Я. Горбачевского МЗ Украины»

РЕЗЮМЕ. Изучение качества жизни (КЖ) во всем мире является одной из актуальных проблем в медицине. Опросники являются надежным и действенным инструментом для измерения КЖ с точки зрения пациента. Шкала часто используется с уверенностью у пациентов с хроническими заболеваниями, нуждающихся в длительной терапии. У пациентов с хроническим панкреатитом (ХП) и сопутствующей анемией чаще встречаются сопутствующие когнитивные нарушения у молодых женщин, больший риск летальности и госпитализаций у взрослыхи особенноупациентов пожилоговозраста, нарушениятерморегуляции, дисфункция иммуннойсистемы, желудочно-кишечные расстройства, инфекция Helicobacter pylori, которые еще больше снижают КЖ. Наше исследование КЖ у пациентов с ХП и ХП с сопутствующим анемическим синдромом с помощью опросников SF-36 и GSRS продемонстрировало значительно более низкий уровень КЖ у пациентов с анемией. Это свидетельствует об объективном отягчающем влиянии сопутствующей анемии на течение основного заболевания.

КЛЮчЕВЫЕ СЛОВА: хронический панкреатит; анемия; качество жизни; SF-36; GSRS. 